\title{
Peroxiredoxin 6 in human brain: molecular forms, cellular distribution and association with Alzheimer's disease pathology
}

\author{
John H. T. Power $\cdot$ Sana Asad $\cdot$ Tim K. Chataway $\cdot$ \\ Fariba Chegini $\cdot$ James Manavis $\cdot$ James A. Temlett $\cdot$ \\ Poul H. Jensen · Peter C. Blumbergs $\cdot$ Wei-Ping Gai
}

Received: 22 January 2008 / Revised: 20 March 2008 / Accepted: 21 March 2008 / Published online: 2 April 2008

(C) Springer-Verlag 2008

\begin{abstract}
Peroxiredoxin 6 is an antioxidant enzyme and is the 1-cys member of the peroxiredoxin family. Using twodimensional electrophoresis and Western blotting, we have shown for the first time that, in human control and brain tissue of patient's with Alzheimer's disease (AD), this enzyme exists as three major and five minor forms with pIs from 5.3 to 6.1. Using specific cellular markers, we have shown that peroxiredoxin 6 is present in astrocytes with very low levels in neurons, but not detectable in microglia or oligodendrocytes. In control brains, there was a very low level of peroxiredoxin 6 staining in astrocytes that was confined to a "halo" around the nucleus. In AD, there were marked increases in the number and staining intensity of peroxiredoxin 6 positive astrocytes in both gray and white matter in the midfrontal cortex, cingulate, hippocampus and amygdala. Confocal microscopy using antibodies to $\mathrm{A} \beta$ peptide, tau and peroxiredoxin 6 showed that peroxiredoxin 6 positive astrocytes are closely involved with diffuse plaques and to a lesser extent with neuritic plaques, suggesting that plaques are producing reactive oxygen species. There appeared to be little astrocytic response to tau containing neurons. Although peroxiredoxin 6 positive astrocytes were seen to make multiple contacts with tau
\end{abstract}

J. H. T. Power $(\varangle) \cdot$ S. Asad · T. K. Chataway · F. Chegini ·

W.-P. Gai

Department of Human Physiology, School of Medicine,

Flinders University, Adelaide 5042, SA, Australia

e-mail: john.power@ flinders.edu.au

J. Manavis - J. A. Temlett · P. C. Blumbergs

Institute of Medical and Veterinary Science,

Adelaide, SA, Australia

P. H. Jensen

Department of Medical Biochemistry,

University of Aarhus, Aarhus, Denmark positive neurons, there was no intraneuronal colocalization. In brain tissue of patients with $\mathrm{AD}$, many blood vessels exhibited peroxiredoxin 6 staining that appeared to be due to the astrocytic foot processes. These results suggest that oxidative stress conditions exist in $\mathrm{AD}$ and that peroxiredoxin 6 is an important antioxidant enzyme in human brain defenses.

Keywords Peroxiredoxin $6 \cdot$ Molecular forms . Alzheimer's disease $\cdot$ Oxidative stress $\cdot$ Astrocytes

\section{Introduction}

Alzheimer's disease (AD) is a neurodegenerative disorder characterized by the progressive decline in memory, language, cognition and motor functions. The neuropathological hallmarks of $\mathrm{AD}$ are the accumulation of extracellular amyloid plaques containing the amyloid beta peptide $(\mathrm{A} \beta)$ and intraneuronal neurofibrillary tangles containing hyperphosphorylated microtubule-associated protein tau. Although the initiating molecular event(s) in AD are not known, oxidative stress produced by the generation of reactive oxygen species (ROS) appears to be a fundamental process contributing to the neuropathophysiology [10]. Whether oxidative stress has a role in the cause or affect in $\mathrm{AD}$ has been debated for many years, but recent research has suggested that it occurs prior to the onset of symptoms [35]. The histopathological evidence for oxidative stress in AD includes lipid, protein and DNA oxidation. There is evidence to suggest that oxidative stress is generated peripherally [26] with the brain being particularly susceptible, but there is also a body of evidence to suggest that amyloid $\beta$ peptide (A $\beta 42)$ may be linked to lipid peroxidation $[5,6]$, which may then be linked to the phosphorylation 
of tau [24]. Two reactive products of $\mathrm{A} \beta 42$-induced lipid peroxidation are the production of four hydroxynonenal and acrolein [5], which have been shown to disrupt membrane asymmetry [7] and may be involved in the conformational changes to tau, promoting the formation of neurofibrillary tangles [24].

Oxidative damage occurs as part of the aging process, but it occurs at a much greater rate in most neurodegenerative diseases [3]. The hallmark of protein oxidation is the generation of protein carbonyls, which are markedly elevated in $\mathrm{AD}[3,16]$. There is overwhelming evidence to implicate oxidative stress in the pathogenesis of $\mathrm{AD}$, and this is most likely an early event in the disease process. Less is known however of how the brain responds to oxidative insults. There are a number of cellular antioxidant defenses whose primary role is to convert the ROS into unreactive compounds. These defense mechanisms include superoxide dismutase, which works together with selenium-dependent glutathione peroxidase, catalase and more recently the peroxiredoxin family. These enzymes transform the superoxide radical to hydrogen peroxide which in turn is converted to water. The distribution and changes in expression of the antioxidant enzymes have not been well studied as the other aspects of the disease process.

Cellular selenium-dependant glutathione peroxidase (GPx-1) has long been regarded as the major cellular antioxidant enzyme, but there are conflicting reports regarding the changes in activities of this enzyme in AD. Early reports suggest that there is no change in GPx-1 activities in $\mathrm{AD}$ brains $[15,20]$, while other researchers suggest that there is a decrease in GPx-1 activity [8, 27, 32]. There are no reports indicating compensatory increase in GPx-1 activity; however, cell models overexpressing GPx-1 are more resistant to $\mathrm{A} \beta$-mediated toxicity, suggesting that increased levels of GPx-1 is protective [2].

There is considerable evidence to implicate $\mathrm{A} \beta$ toxicity and the generation of ROS and in particular hydrogen peroxide as key steps in contributing to the neurotoxicity in AD. We have previously reported that peroxiredoxin 6 , also termed 1 Cys-peroxiredoxin or nonselenium glutathione peroxidase, is upregulated in Parkinson's disease (PD) [30]. This enzyme has no amino acid homology to any known sequence of the glutathione peroxidase enzymes and has both antioxidant and phospholipase A2 activity and can reduce hydroxyperoxides [9]. Given that the brain is particularly vulnerable to oxidative damage due to its high energy and oxygen requirements, high levels of transition metals and peroxidizable fatty acids suggests that peroxiredoxin 6 could play a key antioxidant role in neuroprotection.

There are six members of the peroxiredoxin family at this stage with peroxiredoxins $1-5$ being the 2-Cys members while peroxiredoxin 6 is the sole 1-Cys member [36]. This enzyme is bifunctional with $80 \%$ of its function as a peroxidase and the remainder as a phospholipase A2. Peroxiredoxin 6 has not specifically been examined in brain tissue of $\mathrm{AD}$ patients, and the aims of this study are to examine the molecular forms, cellular distribution and association with AD pathology. This study focused on the cingulate, amygdala, hippocampus and cortical regions in six $\mathrm{AD}$ and six control brains.

\section{Materials and methods}

Antibodies

\section{Primary antibodies}

Peroxiredoxin 6 (rabbit) was obtained from Antibody Technology Australia Pty, Ltd, Adelaide, Australia. Tau (mouse) was obtained from Novacastra Laboratories Ltd, Newcastle, UK. Tau (goat) was obtained from Santa Cruz Biotechnology Inc., California, USA. Amyloid beta (mouse) was obtained from Novacastra Laboratories Ltd, Newcastle, UK. Glial fibrillary acidic protein (GFAP) (mouse) was obtained from Novacastra Laboratories Ltd, Newcastle, UK. Human neuronal protein $\mathrm{HuC} / \mathrm{HuD}$ (mouse) was obtained from Molecular Probes Inc., Eugene, USA. Human HLA (MHC2) (mouse) was obtained from Dakocytomation, Denmark A/S. Myelin basic protein (MBP) (mouse) was obtained from Novacastra Laboratories Ltd, Newcastle, UK.

\section{Secondary antibodies}

Donkey anti sheep Cy3 was obtained from Jackson Immunoresearch, West Grove, USA. Donkey antirabbit $\mathrm{Cy} 3$ and Cy5 were obtained from Jackson Immunoresearch, West Grove, USA. Goat antimouse Alexa 488 was obtained from Molecular Probes Inc., Eugene, USA. Goat antirabbit alkaline phosphatase was obtained from Sigma Chemical Company, St Louis, USA.

\section{Brain tissue}

The brain tissue was obtained from the National Health and Medical Research Council South Australian Brain Bank. Brains were removed at autopsy from clinically diagnosed $\mathrm{AD}$ cases and confirmed pathologically postmortem. The control cases were obtained from people who died of unrelated causes without diagnosed neurological pathology that was confirmed postmortem. The brains were bisected and one half snap-frozen at $-80^{\circ} \mathrm{C}$ and the other immersion fixed in buffered formaldehyde. Tissue blocks were processed and embedded in paraffin and $8 \mu \mathrm{m}$ sections were cut and mounted onto gelatin-coated slides. Table 1 provides a list of the brain regions examined and the case details. 
Table 1 List of cases used in cell counting

\begin{tabular}{|c|c|c|c|c|c|c|c|}
\hline Case number & Sex & Age (years) & Diagnosis & Region & PMI (h) & Braak stage & NIA Reagan \\
\hline $\mathrm{AD} 1$ & M & 65 & $\mathrm{AD}$ & $\mathrm{C}, \mathrm{A}, \mathrm{H}, \mathrm{MC}$ & 3 & $5 / 6$ & High \\
\hline $\mathrm{AD} 2$ & $\mathrm{~F}$ & 84 & $\mathrm{AD}$ & $\mathrm{C}, \mathrm{A}, \mathrm{H}, \mathrm{MC}$ & 16 & $5 / 6$ & High \\
\hline AD3 & M & 63 & $\mathrm{AD}$ & $\mathrm{C}, \mathrm{A}, \mathrm{H}, \mathrm{MC}$ & 33 & $5 / 6$ & High \\
\hline $\mathrm{AD} 4$ & M & 59 & $\mathrm{AD}$ & $\mathrm{C}, \mathrm{A}, \mathrm{H}, \mathrm{MC}$ & 20 & $5 / 6$ & High \\
\hline AD5 & $\mathrm{F}$ & 81 & $\mathrm{AD}$ & $\mathrm{C}, \mathrm{A}, \mathrm{H}, \mathrm{MC}$ & 19 & $5 / 6$ & High \\
\hline AD6 & $\mathrm{F}$ & 69 & $\mathrm{AD}$ & $\mathrm{C}, \mathrm{A}, \mathrm{H}, \mathrm{MC}$ & 38 & $5 / 6$ & High \\
\hline $\mathrm{C} 1$ & $\mathrm{~F}$ & 79 & $\mathrm{ADL}$ & $\mathrm{C}, \mathrm{A}, \mathrm{H}, \mathrm{MC}$ & 4 & & Low \\
\hline $\mathrm{C} 2$ & M & 69 & Unk & $\mathrm{C}, \mathrm{A}, \mathrm{H}, \mathrm{MC}$ & 48 & & Low \\
\hline $\mathrm{C} 3$ & $\mathrm{~F}$ & 61 & $\mathrm{CF}$ & $\mathrm{C}, \mathrm{A}, \mathrm{H}, \mathrm{MC}$ & 8 & & Low \\
\hline $\mathrm{C} 4$ & $\mathrm{~F}$ & 84 & SS & $\mathrm{C}, \mathrm{A}, \mathrm{H}, \mathrm{MC}$ & 15 & & Low \\
\hline $\mathrm{C} 5$ & $\mathrm{~F}$ & 86 & $\mathrm{DM}$ & $\mathrm{C}, \mathrm{A}, \mathrm{H}, \mathrm{MC}$ & 17 & & Low \\
\hline C6 & $\mathrm{F}$ & 86 & HVD & $\mathrm{C}, \mathrm{A}, \mathrm{H}, \mathrm{MC}$ & 6 & & Low \\
\hline
\end{tabular}

PMI postmortem index, $A D$ Alzheimer's disease, NIA Reagan high or low likely-hood of AD, $M$ male, $F$ female, $C$ cingulate, $A$ amygdala, $H$ hippocampus, $M C$ midfrontal cortex, $C$ control, $A D L$ adeno lung carcinoma, Unk unknown, $C F$ cardiac failure, $S S$ septic shock, $D M$ disseminated malignancy, $H V D$ hypertensive vascular disease

\section{Brain homogenate}

Frozen tissue from midfrontal cortex of three AD brains and three control cases were homogenized in $50 \mathrm{mM}$ Tris, $5 \mathrm{mM}$ EDTA, $0.1 \%$ sodium azide, $1 \mu \mathrm{l} / \mathrm{ml}$ pepstatin and leupeptin and $0.3 \mathrm{mM}$ of phenylmethylsulfonyl fluoride. Five milliliters of homogenization buffer was used per gram of brain tissue and homogenized using six passes of a motorized Wheaton Teflon pestle tissue grinder. Homogenates were centrifuged $(500 \times g)$ for $10 \mathrm{~min}$ to remove particulate matter and snap-frozen at $-80^{\circ} \mathrm{C}$. Table 2 provides the details of these cases.

Sample preparation

Aliquots $(100 \mu \mathrm{l})$ of Alzheimer's and control brain homogenates underwent a 2D clean up as per the Amersham Biosciences protocol. The samples were then resolubilized in $300 \mu \mathrm{l}$ of TUC $\mathrm{pH} 4-7$ buffer containing $7 \mathrm{M}$ urea, $2 \mathrm{M}$ thiourea, $4 \%$ CHAPS, $0.5 \%$ dithiothreitol, $0.5 \%$ IPG buffer $\mathrm{pH}$ 4-7. Samples were then assayed for total protein con- tent. Prior to rehydration of the immobilized $\mathrm{pH}$ gradient strips, trace amounts of bromophenol blue was added to samples. Table 2 provides a list of cases used in the 2D electrophoresis.

\section{D polyacrylamide gel electrophoresis (PAGE)}

\section{Isoelectric focusing}

Isoelectric focusing was performed on $13 \mathrm{~cm}$ immobilized $\mathrm{pH}$ gradient strips ( $\mathrm{pH}$ 4-7NL, Amersham Pharmacia) using an IPGphor (Amersham Pharmacia) isoelectric focusing unit. Samples were applied in gel rehydration $(50 \mathrm{~V}$, overnight) using $7 \mathrm{M}$ urea, $2 \mathrm{M}$ thiourea, $4 \%$ CHAPS, $0.5 \%$ dithiothreitol, $0.5 \%$ pharmalyte $\mathrm{pH} 4-7$ with a trace of bromophenol blue as the re-swell buffer with a total loading volume of $280 \mu \mathrm{l}$ including sample. Stained gels received a $400 \mu \mathrm{g}$ protein load and Western blotting gels received a $200 \mu \mathrm{g}$ load. IEF was performed for $\sim 60 \mathrm{kV} \mathrm{h}(500 \mathrm{~V}$ $30 \mathrm{~min}, 1,000 \mathrm{~V} 30 \mathrm{~min}, 1,000-8,000 \mathrm{~V} 30 \mathrm{~min}, 8,000 \mathrm{~V}$ 5-7 h, 1,000 V hold to end).

Table 2 List of cases used for 2D PAGE and Western blots

\begin{tabular}{llllllll}
\hline Case number & Sex & Age (years) & Diagnosis & Region & PMI (h) & Braak stage & NIA Reagan \\
\hline AD7 & F & 69 & AD & MC & 22 & $5 / 6$ & High \\
AD8 & F & 79 & AD & MC & 18 & $5 / 6$ & High \\
AD9 & F & 76 & AD & MC & 23 & High \\
C6 & F & 86 & HVD & MC & 6 & Low \\
C7 & F & 73 & ABD & MC & 24 & Low \\
C8 & M & 63 & SS & MC & 38 & Low
\end{tabular}

$P M I$ postmortem index, $A D$ Alzheimer's disease, $F$ female, $M$ male, $M C$ midfrontal cortex, $C$ control, $H V D$ hypertensive vascular disease, $A B D$ anoxic brain damage, $S S$ septic shock 


\section{SDS PAGE}

SDS PAGE was performed using $12.5 \%$ acrylamide gels. Immobilized $\mathrm{pH}$ gradient strips were incubated in SDS equilibration buffer containing $1 \% \mathrm{w} / \mathrm{v}$ dithiothreitol for 15 min followed by SDS equilibration buffer containing $4 \%$ w/v iodoacetamide for $15 \mathrm{~min}$. Strips were then placed above the second dimension gels and overlaid with $1 \%$ low melting point agarose in Tris glycine gel running buffer. Electrophoresis was performed at $350 \mathrm{~V}$ for $2.5-3 \mathrm{~h}$ at $10^{\circ} \mathrm{C}$. Protein gels were visualized using SYPRO ruby fluorescent stain (incubated for $2 \mathrm{~h}$ ) and scanned using a Typhoon 9400 Variable Mode Imager (Amersham Biosciences).

\section{Western blotting}

Separated proteins were transferred onto low fluorescence PVDF membrane by semi-dry electroblotting at $0.8 \mathrm{~mA} /$ $\mathrm{cm}^{2}$ for $2 \mathrm{~h}$. After blocking, the membranes were incubated in affinity-purified rabbit antiperoxiredoxin 6 antibodies (1/ 2,000 ) overnight at $4^{\circ} \mathrm{C}$ followed by goat antirabbit alkaline phosphatase antibodies $(1 / 10,000)$ (Sigma) for $1 \mathrm{~h}$ and visualized using ECF substrate and a Typhoon 9400 Variable Mode Imager.

Immunohistochemistry

\section{Localization of peroxiredoxin 6}

Immunohistochemical staining of $\mathrm{AD}$ and control tissue was carried out as previously described [30]. The cellular distribution of peroxiredoxin 6 was compared with the staining obtained with antibodies to specific cellular markers. Antibodies to GFAP (astrocytes), HLA (MHC2) (microglia), MBP (oligodendrocytes) and $\mathrm{HuC} / \mathrm{HuD}$ (neurons) were used to map the distribution of peroxiredoxin 6 .

\section{Colocalization of peroxiredoxin $6, A \beta$ and Tau}

Brain sections were incubated with rabbit antiperoxiredoxin 6 , mouse anti $\mathrm{A} \beta$ peptide and goat anti tau antibodies overnight and detected with secondary antibodies conjugated to fluorescent fluorophores Cy5, Alexa 488 and Cy3, respectively. Sections were examined using a Bio-Rad Confocal laser scanning microscope and Bio-Rad software package, as previously described [30].

\section{Cell counting}

Cell counting was carried out blind on masked sections, and peroxiredoxin 6 positive astrocytes were counted at $20 \times$ magnification with a graticule eye piece $\left(0.0625 \mathrm{~mm}^{2}\right)$ using an Olympus HO-2 microscope on brain tissue from six $\mathrm{AD}$ and six control cases. In each case, five regions were randomly selected to give a uniform representation of the white and gray matter in the cingulate, hippocampus, amygdala and midfrontal cortex. The number of positive cells from each of the five areas was averaged and divided by the area of the graticule eyepiece and expressed as cells $/ \mathrm{mm}^{2}$. The data was then analyzed using a one-way ANOVA that examined the interactions listed in Table 3 . The significance was determined at 0.01 level of probability.
Table 3 Interactions examined in cell counting data

$A D$ Alzheimer's disease, $N S$ not significant, $S$ significant, $C$ cingulate, $A$ amygdala, $H$ hippocampus, $M C$ midfrontal cortex

\begin{tabular}{llll}
\hline Interactions examined & $F$ value & $\begin{array}{c}\text { Critical } F \\
(P=0.01)\end{array}$ & $\begin{array}{l}\text { Significance } \\
(>0.01)\end{array}$ \\
\hline $\begin{array}{l}\text { Are there differences in AD (C, A, H, MC) } \\
\text { gray matter cell counts? }\end{array}$ & 1.00 & 4.94 & $\mathrm{NS}$ \\
$\begin{array}{l}\text { Are there differences in AD (C, A, H, MC) } \\
\quad \text { white matter cell counts? }\end{array}$ & 1.23 & 4.94 & $\mathrm{NS}$ \\
$\begin{array}{l}\text { Are there differences in control (C, A, H, MC) } \\
\text { gray matter cell counts? }\end{array}$ & 0.62 & 4.94 & $\mathrm{NS}$ \\
$\begin{array}{l}\text { Are there differences in control (C, A, H, MC) } \\
\text { white matter cell counts? }\end{array}$ & 0.25 & 4.94 & $\mathrm{NS}$ \\
$\begin{array}{l}\text { Are there differences between gray and white } \\
\text { matter cell counts in AD tissue? }\end{array}$ & 89.3 & 7.21 & $\mathrm{~S}$ \\
$\begin{array}{l}\text { Are there differences between gray and white } \\
\text { matter cell counts in control tissue? }\end{array}$ & 14.5 & 7.21 & $\mathrm{~S}$ \\
$\begin{array}{l}\text { Are there differences in gray matter cell counts } \\
\text { between control and AD tissue? }\end{array}$ & 299 & 7.21 & $\mathrm{~S}$ \\
$\begin{array}{l}\text { Are there differences in white matter cell counts } \\
\text { between control and AD tissue? }\end{array}$ & 28.0 & 7.21 & $\mathrm{~S}$ \\
\hline
\end{tabular}




\section{Results}

Molecular forms of peroxiredoxin 6 in human brain

We have previously shown that this antibody is specific for a $26 \mathrm{kDa}$ monomer in rat lung and human brain, and the $\mathrm{N}$ terminal sequence is identical to peroxiredoxin $6[30,31]$. Two-dimensional PAGE and Western blotting of AD and control brain homogenates indicated that this protein exists as three major and five minor forms as shown in Fig. 1a-d.
Although the loadings were consistent, the five minor forms could not be detected on all gels. For comparison, the spots were labeled 1-8 (Fig. 2).

The respective pIs of the eight forms are 5.3, 5.4, 5.6, $5.75,5.85,5.9,5.95$ and 6.1 . The three major forms were 3, 6 and 7 and the average pIs of these were 5.59, 5.88 and 5.96 for AD tissue and 5.59, 5.80 and 5.86 for control tissue. These major forms were consistent in all homogenates. The intensity of the three major forms was analyzed using the Typhoon imager and the intensity of spots 6 and 7 was
Fig. 1 a, b A two-dimensional tissue (Case AD7) and a corresponding control brain gel and blot panels (c, d) (Case C7). pI 4-6 is indicated between the gel and blots and the molecular weight of the standards (Std) in kilo Daltons is shown on the $Y$ axis. The gels were stained with SYPRO ruby fluorescent stain.

The box indicates the location of the molecular forms of peroxiredoxin 6. Some spots are shown on the blots to indicate the range of peroxiredoxin $6 \mathrm{pIs}$ PAGE gel and blot of AD brain
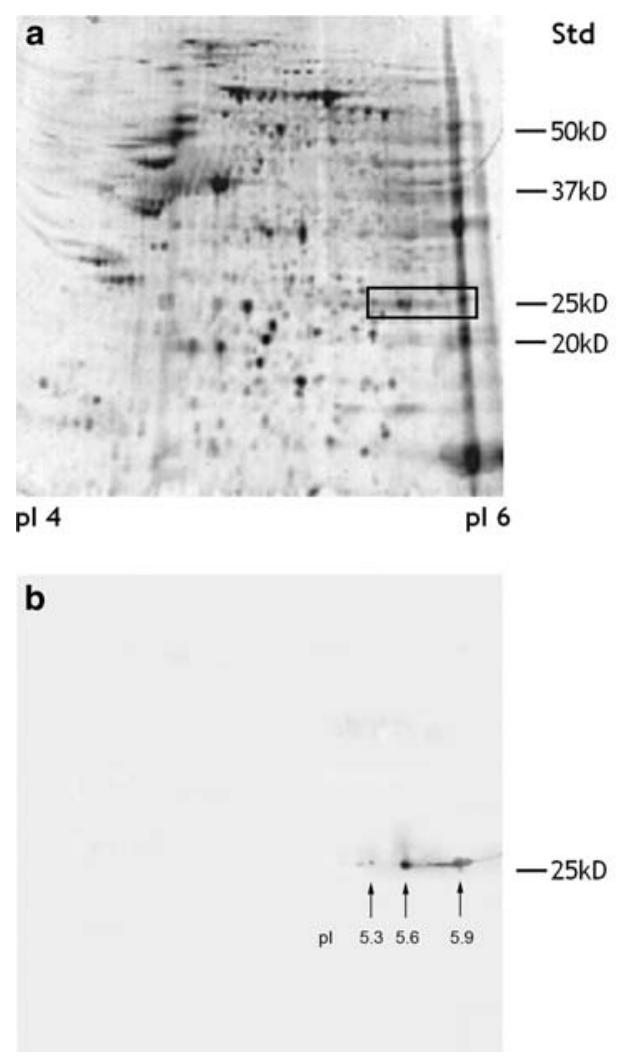

Fig. 2 A composite figure at higher magnification showing the range of molecular forms in three cases of AD tissue (a AD7, AD8 and AD9) and three cases of control tissue (b C7, C6 and C8). The range of molecular forms $1-8$ is shown, but not all forms are present in all cases. Although there are slight variations between blots, the respective pIs are as follows: 1 (5.3), 2 (5.4), 3 (5.6), 4 (5.75), 5 (5.85), 6 (5.9), 7 (5.95), 8 (6.1) a
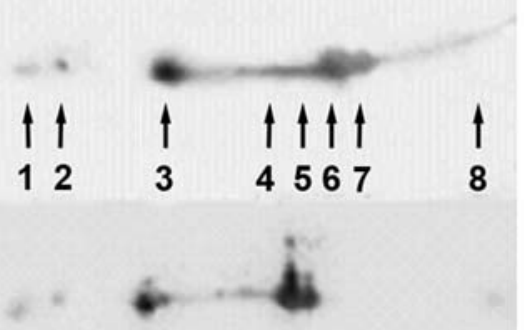

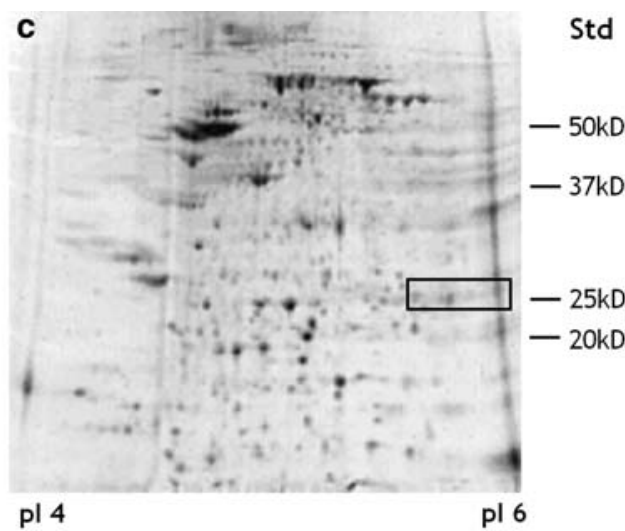

d b

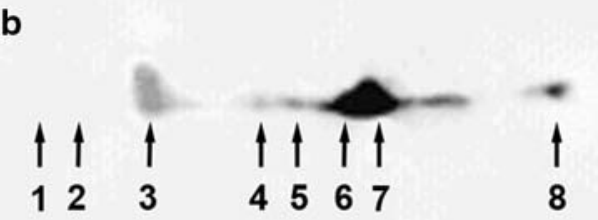


reversed in the $\mathrm{AD}$ and control homogenates (Fig. 2). Minor forms 1 and 2 were present in AD homogenates but absent in the control tissue, while minor form 8 was present in control tissue but absent in AD tissue (Fig. 2).

Cellular distribution of peroxiredoxin 6 in control and $\mathrm{AD}$ brain tissue

Using immunohistochemical markers for specific human brain cell types, we have shown that peroxiredoxin 6 is abundant in reactive astrocytes (Fig. 3a-c) in AD tissue and present in very low levels in neurons (Fig. $3 \mathrm{j}-1$ ). We were not able to detect peroxiredoxin 6 in either microglia (Fig. 3d-f) or oligodendrocytes (Fig. 3g-i).

There was a marked contrast between the staining of control and reactive astrocytes in AD. Reactive astrocytes in $\mathrm{AD}$ were hypertrophied with abundant staining of peroxiredoxin 6 , while in control astrocytes the staining was confined to a "halo" around the nucleus (Fig. 4). The increased staining of peroxiredoxin 6 was seen in all regions examined and in both gray and white matter, but the staining was not evenly distributed and some regions on the same section were heavily labeled but adjacent regions showed little staining (Fig. 5).
Fig. 3 Confocal localization of peroxiredoxin $6(\mathrm{P} 6)$ with GFAP (astrocyte marker) (a P6, Cy2green; b GFAP, Cy3-red; c merged image; bar $25 \mu \mathrm{M}$ ), MHC2 (microglia marker) (d $\mathrm{P} 6$, Cy2-green; e MHC2, Cy3$\mathrm{red} ; \mathbf{f}$ merged image;

bar $25 \mu \mathrm{M}$ ), MBP (oligodendrocyte marker) (g P6, Cy2-green; h MBP, Cy3-red; i merged image; bar $10 \mu \mathrm{M}), \mathrm{Hu}$ (neuronal marker) (j P6, Cy2-green; $\mathbf{k} \mathrm{Hu}$, Cy3-red; 1 merged image; bar $25 \mu \mathrm{M})$. Cell localization was performed using $\mathrm{AD}$ tissue
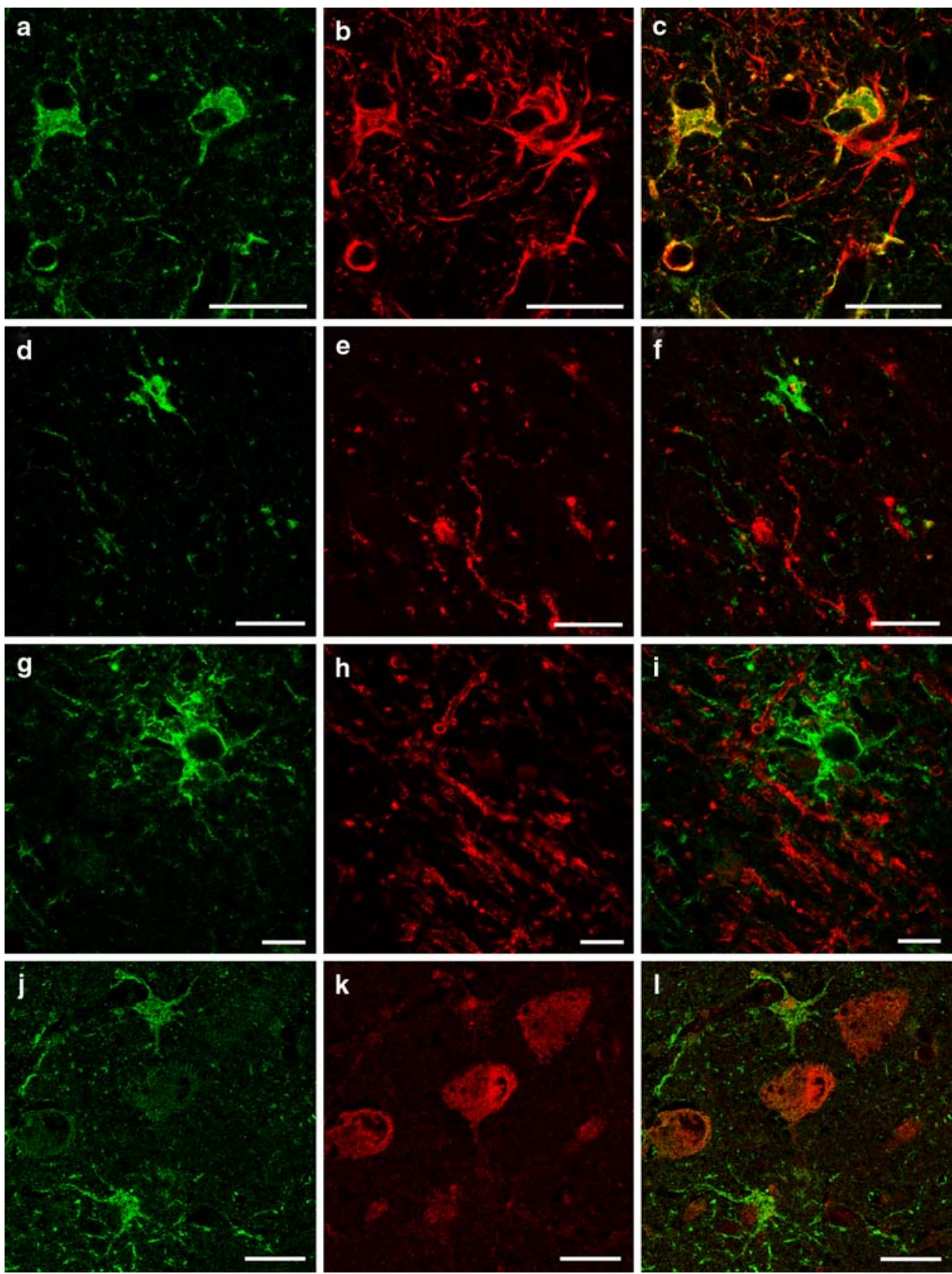
Fig. 4 Oil immersion image $(\times 1,000)$ of typical astrocyte seen in $\mathrm{AD}$ cortex (a) and in control cortex (b)
Fig. 5 Light immunohistochemistry (DAB substrate) of peroxiredoxin 6 staining of astrocytes in $\mathrm{AD}$ gray matter (a), $\mathrm{AD}$ white matter (b), control tissue gray matter (c) and control tissue white matter (d). All images at $\times 200$ magnification
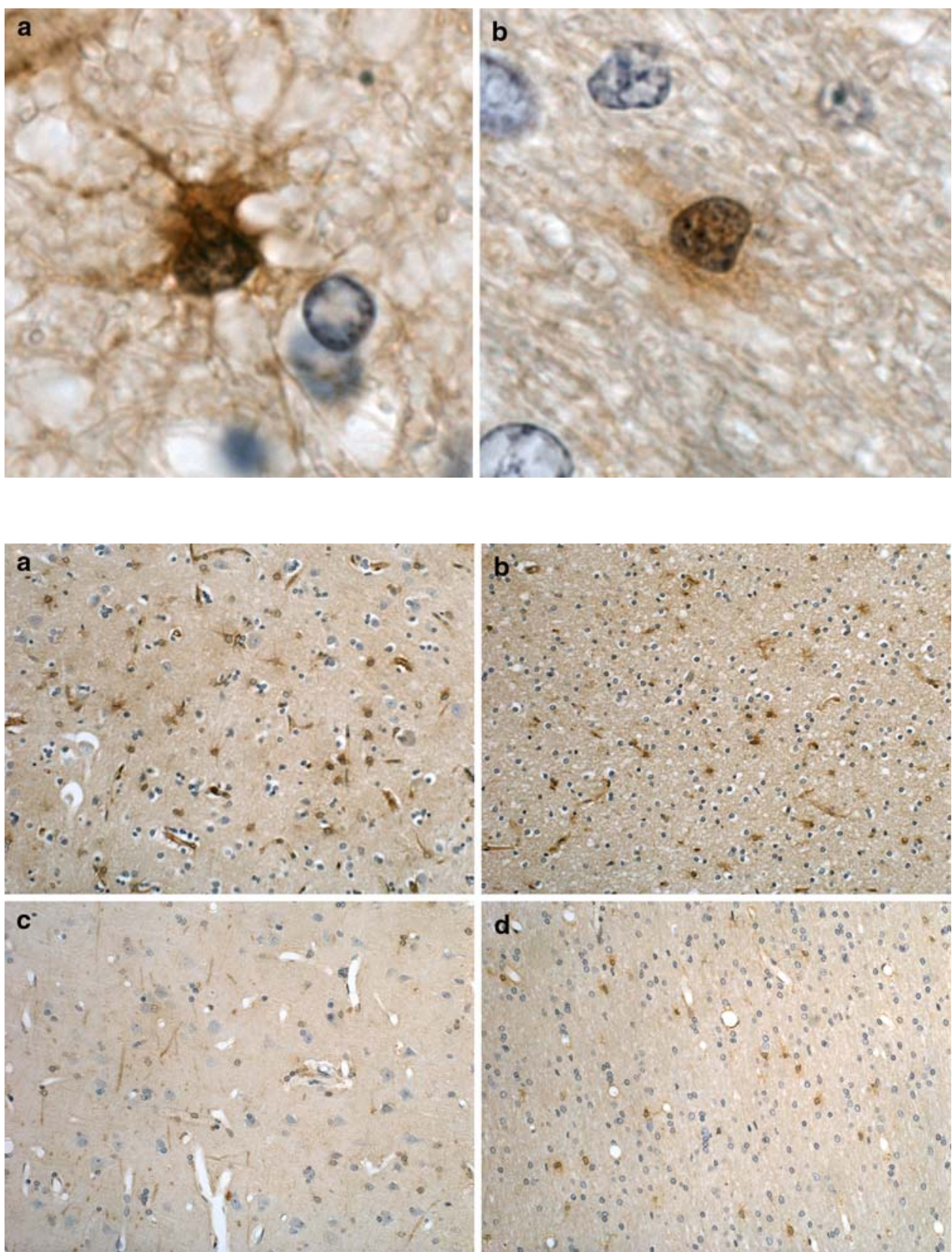

Cell counting

In $\mathrm{AD}$ and control tissue, peroxiredoxin 6 was colocalized with GFAP, indicating that the upregulation is occurring in astrocytes, which is similar to what was found in PD and dementia with Lewy bodies [30]. Cell counting was conducted on midfrontal cortex, cingulate, amygdala and hippocampus brain regions and in gray and white matter to determine if specific areas or matter type were specifically affected. These are summarized in Fig. 6. A one-way ANOVA was performed comparing the cell counts between $\mathrm{AD}$ and control tissue in different regions by tissue and matter type. The results of the interactions examined are shown in Table 3.
Colocalization of peroxiredoxin 6 and AD pathology

The major defining pathology in $\mathrm{AD}$ is the presence of extracellular plaques and intracellular hyperphosphorylated tau in the form of tangles. Plaques are present in brain tissue at different stages of development, ranging from diffuse plaques to fibrillar and neuritic plaques. It is generally considered that diffuse plaques do not contain tau, but neuritic plaques contain both $\mathrm{A} \beta$ and tau. Colocalization of peroxiredoxin 6 and the $\mathrm{A} \beta$ peptide, a major component of plaques, and tau was carried out to determine if peroxiredoxin 6 positive astrocytes were associated with $\mathrm{AD}$ pathology. 


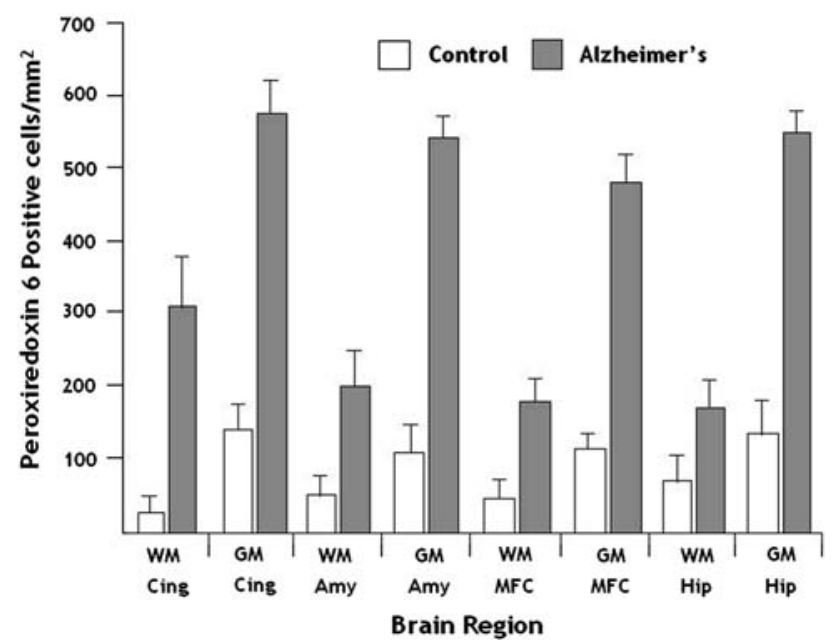

Fig. 6 A bar chart showing the range of cell counts in different brain regions in gray and white matter in control tissue and in AD tissue. $W M$ white matter, GM gray matter, Cing cingulate, Amy amygdala, $M F C$ midfrontal cortex, Hip hippocampus. Counts are shown as mean $\pm \mathrm{SE}$, $N=6$ in all cases

\section{Tau pathology}

Tau deposits in the form of neurofibrillary tangles were observed in many neurons and neurites, and were often surrounded by peroxiredoxin 6 astrocytes, which made multiple contacts (Fig. $7 \mathrm{a}-\mathrm{c}$ ). Although astrocytes made many contacts with neurons, most neurons had very low levels of peroxiredoxin 6 and it did not appear to be upregulated or to be colocalized with tau in AD.

\section{Plaques}

Diffuse plaques contained strongly stained aggregations of $\mathrm{A} \beta$ peptide. Peroxiredoxin 6 staining was confined to astrocytes and their projections that were in close proximity to plaques (Fig. 7d-h). Some astrocytes were observed within plaques, but generally the astrocyte cell bodies were on the periphery with their processes projecting into the plaques. Some plaques contained the beginnings of a dense core of amyloid and took on a "wagon wheel" appearance (Fig. 7i, j). Diffuse plaques and those with A $\beta$ beginning to aggregate appeared to elicit a stronger peroxiredoxin 6 astrocytic response than those with a dense core of $\mathrm{A} \beta$.

\section{Peroxiredoxin 6 staining of blood vessels}

In many regions of the $\mathrm{AD}$ brain, there appeared to be strong peroxiredoxin 6 staining in the walls of many blood vessels, which could be seen to have multiple contacts with strongly staining activated astrocytes (Fig. 7k).

\section{Discussion}

Peroxiredoxin 6, also known as 1-Cys peroxiredoxin or non-selenium glutathione peroxidase, is a human brain antioxidant enzyme that is abundant in activated astrocytes and present in low levels in neurons. On exposure to hydrogen peroxide, the $\mathrm{N}$-terminal peroxiredoxin 6 corresponding to Cys 47 is readily oxidized, but as yet its redox partner has not been identified. Glutathione, lipoic acid and cyclophilin have all been implicated [13, 23, 29]. In addition to its peroxidase activity, peroxiredoxin 6 also has phospholipase A2 activity that might be significant in the brain, which has a high lipid content [9]. Peroxiredoxin 6 staining of astrocytes is markedly elevated in many brain regions in PD and dementia with Lewy bodies [30]. We now show that it is upregulated in the astrocytes in $\mathrm{AD}$ and describe for the first time the range of molecular forms of peroxiredoxin 6 in human brain in both control and AD tissue.

Three major variants and five minor forms were identified with pIs ranging from 5.3 to 6.1. There were three major differences in the peroxiredoxin 6 variants between control and AD tissue. The AD tissue had the two more acidic forms 1 and 2 that were not present in control tissue; the intensity of the major forms 6 and 7 were reversed between $\mathrm{AD}$ and control tissue and minor form 8 was absent in AD tissue. We can only speculate on the significance of these findings at this stage, but different forms may have different affinities for different substrates that might be more abundant under various pathological conditions or the more acidic forms are the result of oxidation [11]. At this stage, we cannot determine whether these differences are true isoforms or post-translational modifications of the same protein, but would suspect the latter. These findings are in agreement with two previous proteomic studies in an $\mathrm{AD}$ mouse model and in human brain $\mathrm{AD}$ tissue, which reported elevated levels of peroxiredoxin 6 [33, 34]. A more recent study using PC12-resistant and PC12 cells treated with $\mathrm{A} \beta$ also reported increased levels of peroxiredoxin 6 [11]. A $\beta$-treated cells contained an extra acidic form, which was suggested to be the result of oxidation of the catalytic cysteine to a sulfenic, sulfinic or sulfonic derivative. We found two minor acidic forms in AD tissue, which is also consistent with this report.

Tissue selection is also a variable that needs to be considered. While the AD tissue had all the hallmarks of AD pathology and was easy to define, age-matched control tissues are somewhat more variable. All the control tissue was from people without clinically defined $\mathrm{AD}$, but most brains in this age group usually contain some neurodegenerative pathology. The age span of the two groups was similar, 59-84 years for the AD group and 61-86 years for the con- 
Fig. 7 a-c Confocal localization of tau within neurons (a Cy2-green) and peroxiredoxin 6 positive astrocytes (b Cy3-red) and (c) the merged image in $\mathrm{AD}$ brain tissue $($ bar $=10 \mu \mathrm{M})$. d-f Confocal localization of $\mathrm{A} \beta$ peptide (d Alexa 488, green) and peroxiredoxin 6 positive astrocytes (e Cy3-red) and (f) the merged image in a diffuse plaque in $\mathrm{AD}$ brain tissue (bar $=50 \mu \mathrm{M})$. $\mathbf{g}-\mathbf{j}$ Confocal localization of $\mathrm{A} \beta$ peptide (Alexa 488 , green) and peroxiredoxin 6 positive astrocytes (Cy5-light blue) in four different plaques in $\mathrm{AD}$ brain tissue (bar $=50 \mu \mathrm{M}$ ). k Immunohistochemical staining (DAB substrate) showing peroxiredoxin 6 staining of astrocytes and astrocyte foot processes in the walls of blood vessels in the midfrontal cortex in Alzheimer's disease $(\times 400)$. Arrows indicate peroxiredoxin 6 positive astrocytic processes
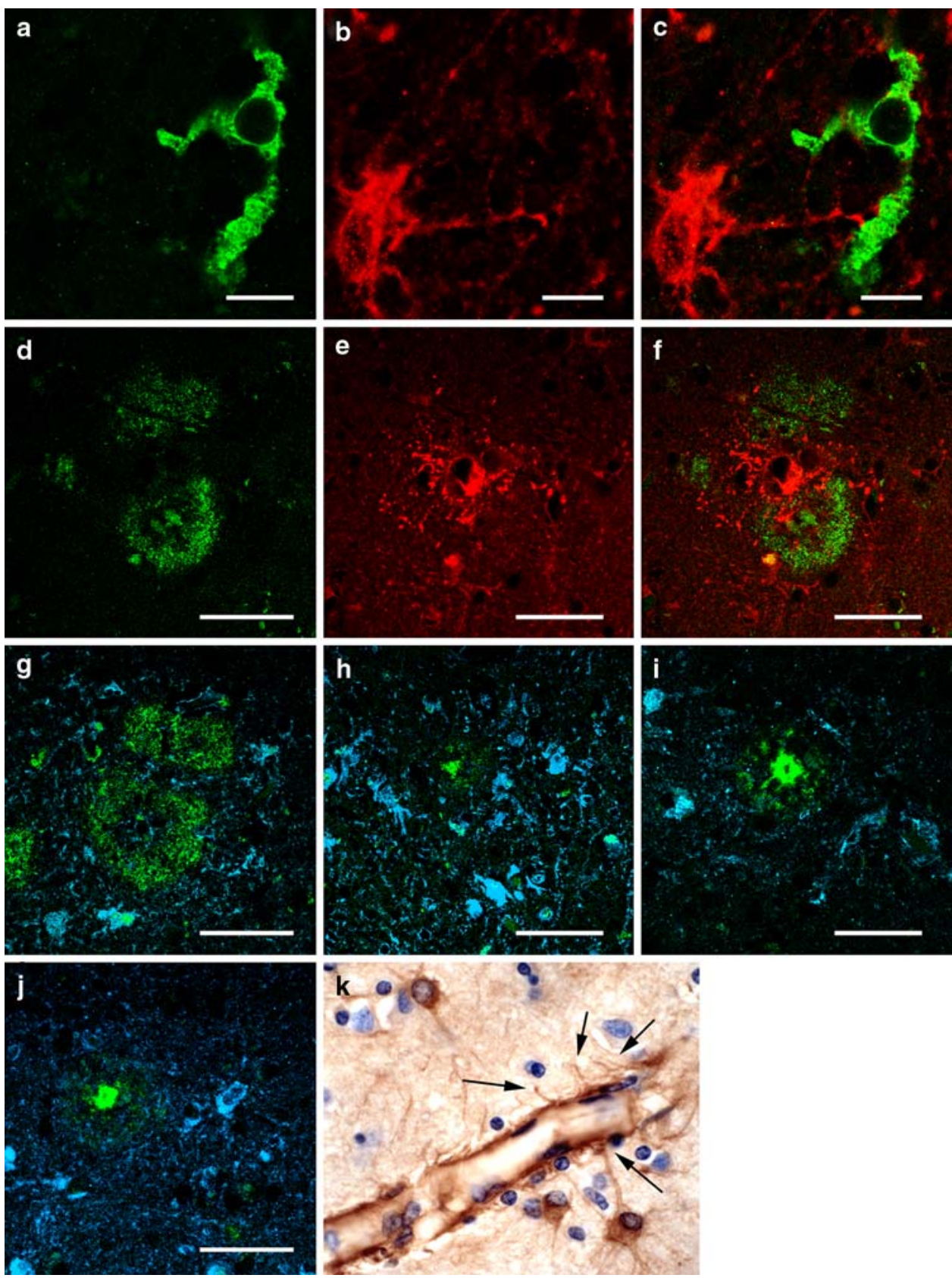

trol group, but the mean age for the control group was 7 years older. We feel confident that, although some control tissue may have had some elements of subclinical AD pathology, the reduced level of astrocyte activation and the clear differences in the cell counting would indicate that all the control tissues were not experiencing high levels of oxidative stress as compared to the AD tissue.

Previously, we had shown that peroxiredoxin 6 was abundant in astrocytes in PD and dementia with Lewy body tissue [30]. We have now used cellular markers to other brain cell types to show that in addition to astrocytes there is a low level in the cytoplasm of most neurons. Unlike astrocytes, neurons do not appear to have increased peroxiredoxin 6 staining in AD tissue. We could not detect any peroxiredoxin 6 staining in microglia or oligodendrocytes.

Cell counting of peroxiredoxin 6 positive astrocytes indicated that there was a marked increase in both the gray and white matter in AD tissue compared with control tissue. Gray matter had more peroxiredoxin 6 positive astrocytes than white matter in both AD and control tissue, and this difference was more pronounced in AD tissue with $F$ values of 89.0 and 14.5 , respectively. Considering that the major pathology (plaques and tangles) is located in the gray matter, it would be expected that oxidative stress is 
more pronounced in this area. Cell counting indicated that the peroxiredoxin 6 positive astrocyte numbers were elevated in all regions examined, suggesting that the insult activating astrocytes is wide spread and not confined to any specific region in either the gray or white matter. Indeed, extracellular plaques were observed in all regions examined in $\mathrm{AD}$ tissue. Although all regions examined showed astrocyte activation, this was not uniformly distributed through all areas, with some areas showing extensive astrocyte activation while adjacent areas were similar to controls.

There are two defining pathologies in $\mathrm{AD}$. These are the presence of extracellular plaques comprising abundant deposits of $\mathrm{A} \beta$ peptides, which later aggregate to form amyloid [25] and intracellular hyperphosphorylated tau aggregations in the form of paired helical filaments, which are termed tangles [14, 22]. The two well-described forms of plaques have been termed diffuse plaques and neuritic or senile plaques $[12,18]$, although other intermediate forms such as fibrillar plaques have been described [12]. Diffuse plaques are spherical structures of less dense $\mathrm{A} \beta$ deposits and are considered an early stage of plaque formation. In diffuse plaques, aggregations of $\mathrm{A} \beta$ exists as nonamyloid deposits, but as the plaque progresses, the $\mathrm{A} \beta$ and other protein aggregations change from the normal conformation into a $\beta$-sheet structure, termed amyloid, and take up specific dyes like Congo red and thioflavin [4]. These plaques do not generally contain tau; however, in many confocal images, diffuse plaques contain focal points of tau, which are probably enlarged neurites. Neuritic or senile plaques contain a dense core of amyloid enriched with $\mathrm{A} \beta$ peptide with a corona of less dense amyloid. The diffuse plaques appeared to elicit a stronger astrocytic response based on the level of peroxiredoxin 6 staining than the neuritic plaques. Our images suggest that once the $\mathrm{A} \beta$ forms amyloid and condenses, it is less stimulating toward astrocytes and perhaps the formation of amyloid is a protective mechanism to inactivate the toxicity of soluble $\mathrm{A} \beta$. These observations are consistent with the findings of KawaguchiNiida et al., who reported that the highly reactive carbonyl crotonaldehyde generated during lipid peroxidation is localized to reactive astrocytes, microglia and diffuse plaques but undetectable in amyloid cores [19].

Although the activation of astrocytes and upregulation of peroxiredoxin 6 would be considered a protective response, in cell culture, soluble $\mathrm{A} \beta$ has been shown to stimulate nitric oxide synthetase and the production of nitric oxide, which is very damaging to neurons [17]. This response is further upregulated by other inflammatory cytokines such as interleukin $1 \beta$ and tumour necrosis factor- $\alpha$, which are reported to be released from astrocytes [1]. At this stage, we are not sure of the net benefit to neural tissue of activated astrocytes with elevated levels of peroxiredoxin 6 , concomitant with the increased production of nitric oxide.

Neurofibrillary tangles comprising hyperphosphorylated tau were observed in many regions in $\mathrm{AD}$ tissue. Two antibodies were used to localize tau, a monoclonal antibody (Novacastra) and one specific for paired helical filaments (Santa Cruz) and both produced a similar staining pattern. Neurons containing tau were not surrounded by activated astrocytes as were the diffuse plaques and to a lesser extent the neuritic plaques, suggesting that these cells are not secreting toxic or activating products that are stimulating to astrocytes. In PD, Lewy bodies contained a dense core of peroxiredoxin 6 staining suggesting that it was trying to detoxify oxidative stress produced by Lewy bodies, but we did not observe any interaction between tau and peroxiredoxin 6 in $\mathrm{AD}$ tissue. Although there is considerable evidence to implicate oxidative stress in the hyperphosphorylation of tau, this does not appear to upregulate peroxiredoxin 6 in tau positive neurons.

In some regions, the walls of blood vessels exhibited strong peroxiredoxin 6 staining, which also elicited a strong astrocytic response in surrounding astrocytes. These activated astrocytes had many processes in contact with the endothelial cells. Although vascular amyloid deposits were seen in some sections and is a key feature of $\mathrm{AD}$ [28], the upregulation of peroxiredoxin 6 appeared to occur in regions without distinct $\mathrm{A} \beta$ staining. $\mathrm{A} \beta$ has been shown to induce vascular vasoconstriction in rat skin, which can be reversed by superoxide dismutase and catalase, indicating that $\mathrm{A} \beta$ is capable of generating ROS within blood vessels [21]. The blood brain barrier consists of the capillary endothelial cells, and the foot processes of the astrocytes and the fused basal lamina of both cells. The peroxiredoxin 6 staining within the capillaries appears to be in the foot processes of the astrocytes. Whether this increased staining is due to ROS generated from within neural tissue or reflects a more systemic pathology derived from the circulation is unclear.

In conclusion, we have shown for the first time the range of peroxiredoxin 6 variants, which are either isoforms or post-translational modifications in human brain tissue. We have also shown that peroxiredoxin 6 is primarily an astrocytic enzyme with very low levels in neurons and is not detectable in microglia or oligodendrocytes. This enzyme is markedly elevated in astrocytes in both white and gray matter in AD. Strongly staining peroxiredoxin 6 astrocytes appear to be involved in the detoxification of diffuse plaques and to a lesser extent in neuritic plaques, but is not associated with tau aggregations within neurons. From this work and previous work on PD and dementia with Lewy bodies, we suggest that peroxiredoxin 6 is a major antioxidant enzyme in human neural tissue. 
Acknowledgments We gratefully acknowledge the excellent assistance of the Flinders University Proteomics Facility and the Flinders University Microscopy and Image Analysis Facility. This work was supported by the Flinders Medical Centre Foundation, Flinders University Faculty Grant and the National Health and Medical Research Council (Grant ID 275528).

\section{References}

1. Akama KT, Van Eldik LJ (2000) $\beta$-amyloid stimulation of inducible nitric oxide synthetase in astrocytes is interleukin- $1 \beta$ and tumour necrosis factor- $\alpha(\mathrm{TNF} \alpha)$-dependent, and involves a TNF $\alpha$ receptor-associated factor and $\mathrm{NKF} \kappa \mathrm{B}$-inducing kinase-dependent signalling mechanism. J Biol Chem 275:7918-7924

2. Barkats M, Millecamps S, Abrioux P, Geoffroy MC, Mallet J (2000) Overexpression of glutathione peroxidase increases the resistance of neuronal cells to $\mathrm{A} \beta$-mediated neurotoxicity. J Neurochem 75:1438-1446

3. Beal MF (2002) Oxidatively modified proteins in aging and disease. Free Radic Biol Med 32:797-803

4. Burdick D, Soreghan B, Kwon M, Kosmoski J, Knauer M, Henschen A, Yates J, Cotman C, Glabe C (1992) Assembly and aggregation properties of synthetic Alzheimer's A4/ $\beta$ amyloid peptide analogs. J Biol Chem 267:546-554

5. Butterfield DA, Castegna A, Lauderback C M, Drake J (2002) Evidence that amyloid beta-peptide-induced lipid peroxidation and its sequelae in Alzheimer's disease brain contribute to neuronal death. Neurobiol Aging 23:655-664

6. Butterfield DA, Lauderback CM (2002) Lipid peroxidation and protein oxidation in Alzheimer's disease brain: potential causes and consequences involving amyloid $\beta$-peptide-associated free radical oxidative stress. Free Radic Biol Med 32:1050-1060

7. Castegna A, Lauderback CM, Mohmmad-Abdul H, Butterfield DA (2004) Modulation of phospholipid asymmetry in synaptosomal membranes by the lipid peroxidation products, 4-hydroxynonenal and acrolein: implications for Alzheimer's disease. Brain Res 1004:193-197

8. Chen L, Richardson JS, Calwell JE, Ang LC (1994) Regional brain activity of free radical defence enzymes in autopsy samples from patients with Alzheimer's disease and nondemented controls. Int J Neurosci 75:83-90

9. Chen J, Dodia C, Feinstein SI, Jain MK, Fisher AB (2000) 1-Cys peroxiredoxin, a bifunctional enzyme with glutathione peroxidase and phospholipase $\mathrm{A}_{2}$ activities. J Biol Chem 275:28421-28427

10. Chong ZZ, Li F, Maiese K (2005) Stress in the brain: novel cellular mechanisms of injury linked to Alzheimer's disease. Brain Res Rev 49:1-21

11. Cummings RC, Dargusch R, Fischer WH, Schubert D (2007) Increase in expression levels and resistance to sulfhydryl oxidation of peroxiredoxin isoforms in amyloid $\beta$-resistant nerve cells. $\mathbf{J}$ Biol Chem 282:30523-30534

12. Dickson TC, Vickers JC (2001) The morphological phenotype of $\beta$-amyloid plaques and associated neuritic changes in Alzheimer's disease. Neuroscience 105:99-107

13. Fisher AB, Dodia C, Manevich Y, Chen JW, Feinstein SI (1999) Phospholipid hydroperoxides are substrates for non-selenium glutathione peroxidase. J Biol Chem 274:21326-21334

14. Grundke-Iqbal I, Iqbal K, Tung Y, Quinlan M, Wisniewski HM, Binder L (1986) Abnormal phosphorylation of the microtubuleassociated protein $\tau$ (tau) in Alzheimer cytoskeletal pathology. Proc Natl Acad Sci USA 83:4913-4917

15. Hayn M, Kremser K, Singewald N, Cairns N, Nemethova M, Lubec B, Lubec G (1996) Evidence against the involvement of reactive oxygen species in the pathogenesis of neuronal death in Down's syndrome and Alzheimer's disease. Life Sci 57:537-544

16. Hensley K, Hall N, Subramaniam R, Cole P, Harris M, Aksenov M, Aksenova M, Gabbita SP, Wu JF, Carney JM, Lovell M, Markesbery WR, Butterfield DA (1995) Brain regional correspondence between Alzheimer's disease histopathology and biomarkers of protein oxidation. J Neurochem 65:2146-2156

17. Hu J, Akama KT, Krafft GA, Chromy BA, Van Eldik LJ (1998) Amyloid- $\beta$ peptide activates cultured astrocytes: morphological alterations, cytokine induction and nitric oxide release. Brain Res 785:195-206

18. Kato S, Gondo T, Hoshii Y, Takahashi M, Yamada M, Ishihara T (1998) Confocal observation of senile plaques in Alzheimer's disease: senile plaque morphology and relationship between senile plaques and astrocytes. Pathol Int 48:332-340

19. Kawaguchi-Niida M, Shibata N, Morikawa S, Uchida K, Yamamoto T, Sawada T, Kobayashi M (2006) Crotonaldehyde accumulates in glial cells of Alzheimer's disease brain. Acta Neuropathol 111:422-429

20. Kish SJ, Morito CL, Hornykiewicz O (1986) Brain glutathione peroxidase in neurodegenerative disorders. Neurochem Pathol 4:23-28

21. Khalil Z, Poliviou H, Maynard CJ, Beyreuther K, Masters CL, Li QX (2002) Mechanism of peripheral microvascular dysfunction in transgenic mice overexpressing the Alzheimer's disease amyloid Abeta protein. J Alzheimers Dis 4:467-478

22. Kosik KS, Joachim CL, Selkoe DJ (1986) Microtubule-associated protein tau $(\tau)$ is a major component of paired helical filaments in Alzheimer disease. Proc Natl Acad Sci USA 83:4044-4048

23. Lee SL, Hwang YS, Kim YJ, Kwon K, Kim HJ, Kim K, Chae HZ (2001) Cyclophilin A binds to peroxiredoxins and activates its peroxidase activity. J Biol Chem 276:29826-29832

24. Liu Q, Smith MA, Avila J, DeBernardis J, Kansal M, Takeda A, Zhu X, Nunomura A, Honda K, Moreira PI, Oliveira CR, Santos MS, Shimohama S, Aliev G, de la Torre J, Ghanbari HA, Siedlak SL, Harris PLR, Sayre LM, Perry G (2005) Alzheimer-specific epitopes of tau represent lipid peroxidation-induced conformations. Free Radic Biol Med 38:746-754

25. Masters CL, Simms G, Weinman NA, Multhaup G, McDonald BL, Beyreuther K (1985) Amyloid plaque core protein in Alzheimer's disease and Down syndrome. Proc Natl Acad Sci USA 82:4245-4249

26. Migliore L, Fontana I, Trippi F, Colognato R, Coppede F, Tognoni G, Nucciarone B, Siciliano G (2005) Oxidative DNA damage in peripheral leukocytes of mild cognitive impairment and AD patients. Neurobiol Aging 26:567-573

27. Omar RA, Chyan YJ, Andorn AC, Poeggeler B, Robakis NK, Pappolla MA (1999) Increased expression but reduced activity of antioxidant enzymes in Alzheimer's disease. J Alzheimers Dis 1:139-145

28. Pardridge WM, Vinters HV, Yang J, Eisenberg J, Choi TB, Touretellotte WW, Huebner V, Shively JE (1987) Amyloid angiopathy of Alzheimer's disease: amino acid composition and partial sequence of a 4,200-dalton peptide isolated from cortical microvessels. J Neurochem 49:1394-1401

29. Peshenko IV, Shichi H (2001) Oxidation of active center cysteine of bovine 1-Cys peroxiredoxin to the cysteine sulfenic acid form by peroxide and peroxynitrite. Free Radic Biol Med 31:292-303

30. Power JHT, Shannon JM, Blumbergs PC, Gai W (2002) Nonselenium glutathione peroxidase in human brain: elevated levels in Parkinson's disease and dementia with Lewy bodies. Am J Pathol 161:885-894

31. Power JHT, Nicholas TE (1999) Immunohistochemical localization and characterization of a rat Clara cell $26-\mathrm{kDa}$ protein (CC26) with similarities to glutathione peroxidase and phospholipase A2. Exp Lung Res 25:379-392 
32. Romero FJ, Bosch-Morell F, Romero MJ, Jareno EJ, Romero B, Marin N, Roma J (1998) Lipid peroxidation products and antioxidants in human disease. Environ Health Perspect 106:1229-1234

33. Schonberger SJ, Edgar PF, Kydd R, Faull RLM, Cooper GJS (2001) Proteomic analysis of the brain in Alzheimer's disease: molecular phenotype of a complex disease process. Proteomics $1: 1519-1528$

34. Sizova D, Charbaut E, Delalande F, Poirier F, High AA, Parker F, Dorsselaer F, Duchesne M, Diu-Hercend A (2007) Proteomic analysis of brain tissue from an Alzheimer's disease mouse model by two-dimensional difference gel electrophoresis. Neurobiol Aging 28:357-370

35. Smith MA, Nunomura A, Lee H, Zhu X, Moreira PI, Avila J, Perry $G$ (2005) Chronological primacy of oxidative stress in Alzheimer's disease. Neurobiol Aging 26:579-580

36. Wood ZA, Schroder E, Harris JR (2003) Poole LB Structure, mechanism and regulation of peroxiredoxins. Trend Biochem Sci 28:32-40 